\title{
Forecasting future performance of irrigation schemes: The case of Bergama
}

\author{
Sinan Kartal ${ }^{1, a, *}$ \\ ${ }^{1}$ Alanya Alaaddin Keykubat University, 07425 Alanya/Antalya, Turkey \\ *Corresponding author \\ A R T I C L E I N F O A B S T R A C T \\ Research Article \\ Potential outputs of irrigation should be put forth to improve the yields in agricultural practices. \\ Available water resources should efficiently be used to improve yields and inputs should be \\ minimized. Performance assessment of irrigation schemes is an importance issue for improved \\ yields and to take relevant measured. Statistical methods are used for performance assessment of \\ Received : 30/12/2020 \\ Accepted : 16/02/2021 \\ irrigation schemes with the use of various indicators. Forecasts for future performance of irrigation \\ shames will facilitate the steps to be taken by decision-makers to improve performance. In this \\ study, time series - ARIMA method was used to forecast future performance of Bergama irrigation \\ scheme for 2017-2021 period. The indicator values of annual irrigation water supply per unit \\ command area, output per unit command area and total expenditure per unit command area for \\ 2006-2017 period were used to estimate performance indicators for 2017-2021 period. In 2021, at \\ Keywords: \\ Irrigation \\ Irrigation performance \\ Irrigation scheme \\ Time-series-forecasting \\ Performance indicators \\ 95\% probability, the lowest annual irrigation water supply per unit-command area was calculated \\ as $4365.10 \mathrm{~m}^{3} \mathrm{ha}^{-1}$ and the highest as $16835.69 \mathrm{~m}^{3} \mathrm{ha}^{-1}$; the lowest output per unit command area \\ was calculated as $-5076.10 € \mathrm{ha}^{-1}$ and the highest as $10401.2 € \mathrm{ha}^{-1}$; the lowest total expenditure per \\ unit command area was calculated as $-2200.41 €$ ha $^{-1}$ and the highest as $1866.31 €$ ha $^{-1}$. Present \\ forecasts of time series -ARIMA method with the use of data of 2006-2016 period revealed that \\ annual irrigation water supply per unit-command area and output per unit command area will \\ increase and total expenditure per unit command area will decrease in years.
}

a sinan.kartal@alanya.edu.tr (i) https://orcid.org/0000-0002-9600-8052|

\section{Introduction}

Water is an essential component of life on earth and water resources are continuously depleting with increasing world population. Global warming and climate change further aggravate the water-related problems. Then, efficient and sustainable use of vital resources have become critical issues in world agenda. Food supply of increasing populations have also become a challenging issue. Meeting requirement food demands will be possible only with maximum or optimum use of available resources in agriculture.

Water is the primary input in agriculture. Current research mostly focuses on efficient use of water resources. In Turkey, annual water consumption of different sectors reached to 57 billion $\mathrm{m}^{3}$ (DSI, 2019). Of such a quantity, about 44,0 billion $\mathrm{m}^{3}(77 \%)$ are used in irrigation, about 13 billion $\mathrm{m}^{3}(26 \%)$ are used for domestic and industry (DSI, 2019). According to National Water Plan 2019-2023, migrations from rural parts to urban sections and rapidly increasing populations increased demands for agriculture, already using $74 \%$ of available water resources of Turkey.
Together with accelerated developments achieved in industry, industrial water use reached to $13 \%$ level and in $13 \%$ in domestic use (Anonymous, 2020; DSI, 2019). Such a high level of water uses in industry exerted a pressure on agricultural sector in terms of quality, rather than quantity of water.

Turkey has 25 river basins and monitoring programs have been prepared in accordance with EU norms. Watershed Management Plans are being prepared and targeted to be completed by the year 2023. An efficient supply-and-demand balance is totally dependent on proper identification of intersectoral water use demands. In Turkey, during the last 20 years, a $40 \%$ increase was seen in total water consumption. Considering the population growth rate and growth of agricultural, domestic, industrial and energy sectors, it was projected that amount of water needed within the next 25 years will triple the present water consumption. Such increasing demands will further increase the pressure exerted on water resources. By the year 2030, Turkey planned to use 112 billion $\mathrm{m}^{3}$ of 
available water resources and allocate $64 \%$ of this source to agriculture, $20 \%$ to industrial uses and $16 \%$ to domestic uses (Şura, 2017). Considering the current use in agriculture (74\%), it was thought that water use performance in agriculture should be well-assessed and planed accordingly. By the year 2017, total size of lands opened for irrigation reached to 6,5 million hectares constituting about $72 \%$ of economically irrigable lands of Turkey. In 2016, net irrigation area was 3 million hectares (DSI, 2019). Majority of irrigable lands (75-80\%) is irrigated with surface waters and the rest is irrigated with groundwater. In 2016, 43 billion $\mathrm{m}^{3}$ water was used in irrigation and $77 \%$ of this water was supplied from surface water and $23 \%$ from groundwater (State Hydraulic Works, 2017). Leakage and evaporative losses are generally encountered in traditional systems. Through transition from traditional systems into modern systems, serious effort has been spent to improve irrigation efficiency, but overall efficiency is still around 51\% level. National Water Plan 2019-2023 (2019) targets to increase efficiency to $55 \%$ level by the year 2024 .

Several studies have been conducted worldwide about water use. McGlade et al. (2012) and Millennium Ecosystem Assessment (MEA, 2005) indicated that water was perceived as a renewable but limited resource in several countries and regions and excessive use of available water resources will aggravate water stress and exert serious threats on ecosystems and biodiversity. Shiklomanov and Rodda (2003) indicated agricultural irrigations, constituting about $86 \%$ of annual global water consumption, as the most significant factor for water consumption. Limited nature of water and ever-increasing water demands have made water use and management even more the significant issues. Several studies indicated that relevant measures should be taken to improve efficiency in water use and management, otherwise mankind will encounter several water-related problems (Alcamo et al. 1997; Seckler et al. 1998; Falkenmark and Rockström, 2004 ). There are several studies conducted on agricultural water use and management. Various indicators were developed to assess the performance of irrigation schemes (Molden et al., 1998; Malano and Burton, 2001; Burt, 2001; Renault et al., 2007). Several studies were also conducted with the use of these indicators (Çakmak 2001; Değirmenci, 2004; Rodriguez-Diaz et al., 2008; Corcoles et al., 2010; Alcon et al., 2017; Zema et al., 2018; Arslan and Değirmenci, 2018; Kartal et al., 2019; Kartal et al., 2020). Majority of these studies conducted to assess and compare the performance of irrigation organizations. In this study, current data of Bergama irrigation scheme located in İzmir province of Turkey were used to calculate future performance of the irrigation scheme with the use of performance indicators. Recommendations were provided to improve estimated future performance of the irrigation scheme.

\section{Material and Method}

The data supplied from General Directorate of State Hydraulic Works (DSI) for Bergama irrigation scheme for the years 2006-2019 period were used as the primary material of the present study. Data was obtained from DSI annual reports (DSI, 2019). Bergama irrigation scheme has an irrigation area of 3716 ha and uses gravity irrigation. The irrigation scheme has a total canal length of $25,9 \mathrm{~km}$, of which $20 \mathrm{~km}$ is lined-canal and $5,9 \mathrm{~km}$ is canalette. Irrigation water is supplied from Kestel and Bergama rivers. About $5 \%$ of irrigations are performed with classical system and $95 \%$ are performed with canalette system. About 2892 ha (78\%) of irrigation area is actively irrigated. Changing with the years, respectively maize, cotton and vegetables are mostly grown in irrigation district.

\section{Method}

Data of 2006-2016 period of Bergama irrigation scheme were used to make estimations for 2017-2021 period. Annual irrigation water supply per unit command area, total expenditure per unit command area and output per unit command area were used as performance indicators. Equations provided in Table 1 were used to calculate the performance indicators used to determine the performance of Bergama irrigation scheme (Bos et al., 1994; Molden et al., 1998; Malano and Burton, 2001; Burt, 2001; Renault et al., 2007).

\section{Data Analysis}

Data of 2006-2016 period were used in time series analysis to estimate the performance for 2017-2021 period. ARIMA is the strongest model used in future estimations with time series analysis (Box et al., 1994). The method is composed of model definition, parameter estimation and identification model validity phases. ARIMA compares different models while identifying the best model for relevant data (Nelson, 1991; Engle, 1982; Campbell and Diebold, 2005). Comparisons reveal the best ARIMA ( $p$, d, q) arrangement and offers fit indices. Potential models are compared with the use of ARIMA and then a decision is made about which model was more appropriate for relevant data and forecasting. Assessments are made based on Bayes Information Criteria (BIC) and some goodnessof-fit statistics (Neath and Cavanaugh, 2017).

Table 1. Performance indicators used in calculations and calculation methods

\begin{tabular}{l|c}
\hline \multicolumn{1}{c|}{ Indicators } & Definition \\
\hline Annual irrigation water supply per unitcommand area $\left(\mathrm{m}^{3} \mathrm{ha}^{-1}\right)$ & $\frac{\text { Total annual volume of irrigation supply }}{\text { Total annual irrigated area }}$ \\
Total expenditure per unit command area $\left(€ \mathrm{ha}^{-1}\right)$ & $\frac{\text { Total expenditure }}{\text { Command area }}$ \\
Output per unit command area $\left(€ \mathrm{ha}^{-1}\right)$ & $\frac{\text { Total annual value of agricultural production }}{\text { Command area }}$ \\
\hline
\end{tabular}


Table 2. Codes used for analysis

\#\#\# The code used to download the used package \#\#\#

>install.packages("forecast")

>library(forecast)

\#\#\# code used in time series generation\#\#\#

$>\mathrm{Y}<-\mathrm{ts}($ data $\$$ variable, start $=\mathrm{c}($ year, 1$), \mathrm{f}=1)$

\#\#\# Code used for modeling with ARIMA\#\#\#

$>$ fitarima $<$-auto.arima $(Y$, stepwise $=F$, approximation $=F$, trace $=T$, seasonal $=F$ )

\#\#\#code used for estimation\#\#\#

$>$ fc $<$ - forecast(fitarima, $\mathrm{h}=5$

\#\#\#The code used to draw the forecast chart\#\#\#

$>$ plot(fc, main="...", ylab="...", xlab="...")

\#\#\# The code that prints out the modeling made with ARIMA\#\#\#

$>$ print(summary(fitarima))

\#\#\# the code used to print the estimated values \#\#\#

$>\operatorname{print}(\operatorname{summary}(\mathrm{fc}))$

While deciding about which ARIMA model is more suitable, BIC, Root Mean Square Error of Approximation (RMSE), Mean Absolute Percentage Error (MAPE), Mean Absolute Error (MAE) and Logistic Likelihood (LL) values were used. Parameters, in other words forecasts, are obtained through maximum likelihood asymptotically true for time series (Mandal, 2005). In present study, "forecast" package of R software was used in formation of time series, parameter estimations and forecasts. Analyses were conducted with the following code are given in Table 2 .

\section{Results}

In this chapter, model information about performance indicators, fit indices and estimation results were presented.

For Bergama irrigation scheme data, ARIMA $(0,1,0)$ model was selected for annual irrigation water supply per unit command area; $(0,1,0)$ was selected for output per unit command area and $(0,1,0)$ was selected for total expenditure per unit command area. The forecasts made for 2017-2021 period with the use of specified ARIMA models were provided below respectively for annual irrigation water supply per unit command area, output per unit command area and total expenditure per unit command area.

Variations and estimations of annual irrigation water supply per unit command area are presented in Figure 1. Forecast upper limits for the years 2017-2021 increased gradually within the years. Therefore, it could be stated that total annual irrigation water supply per unit command area will increase gradually. Estimations for the years 20172021 are provided in Table 3.

Table 3. Fit indexes of ARIMA models

\begin{tabular}{|c|c|c|c|c|}
\hline \multirow{2}{*}{ Performance indicators } & \multicolumn{3}{|c|}{ Fit Statistics } & \multirow{2}{*}{ Model } \\
\hline & \multirow{2}{*}{\multicolumn{4}{|c|}{ 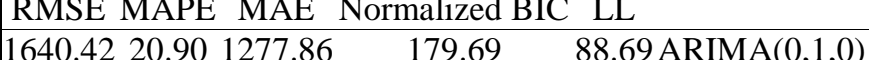 }} \\
\hline Annual irrigation water delivery per unit command area & & & & \\
\hline Output per unit command area & 1683.5824 .081276 .63 & 180.21 & 88.95 & $\mathrm{IMA}(0,1,0)$ \\
\hline Total expenditure per unit command area & $126.53 \quad 11.14 \quad 100.77$ & 116.67 & 57.24 & $\operatorname{IMA}(0,2,0)$ \\
\hline
\end{tabular}

Table 4. Annual irrigation water delivery per unit command area estimates

\begin{tabular}{l|ccccc}
\hline Years & Lower $(\% 95)$ & Lower $(\% 80)$ & Forecast & Upper $(\% 80)$ & Upper $(\% 95)$ \\
\hline 2017 & 7090.51 & 5923.30 & 9295.42 & 11500.32 & 12667.53 \\
2018 & 6177.21 & 4526.53 & 9295.42 & 12413.63 & 14064.31 \\
2019 & 5476.41 & 3454.75 & 9295.42 & 13114.43 & 15136.09 \\
2020 & 4885.61 & 2551.19 & 9295.42 & 13705.23 & 16039.64 \\
2021 & 4365.10 & 1755.15 & 9295.42 & 14225.74 & 16835.69 \\
\hline
\end{tabular}


Table 5. Output per unit command area estimates

\begin{tabular}{c|ccccc}
\hline Years & Lower $(\% 80)$ & Lower $(\% 95)$ & Forecast & Upper $(\% 95)$ & Upper (\%80) \\
\hline 2017 & 399.63 & -798.28 & 2662.55 & 6123.38 & 4925.46 \\
2018 & -537.69 & -2231.80 & 2662.55 & 7556.90 & 5862.79 \\
2019 & -1256.93 & -3331.78 & 2662.55 & 8656.88 & 6582.03 \\
2020 & -1863.28 & -4259.11 & 2662.55 & 9584.21 & 7188.38 \\
2021 & -2397.48 & -5076.10 & 2662.55 & 10401.2 & 7722.58 \\
\hline \multicolumn{7}{l}{ Table 6. Total expenditure per unit command area estimates } & & & Upper $(\% 80)$ \\
\hline \multicolumn{7}{r}{ Years } & Lower $(\% 80)$ & Lower $(\% 95)$ & Forecast & Upper $(\% 95)$ & 738.66 \\
\hline 2017 & 380.11 & 285.21 & 559.39 & 833.56 & 778.65 \\
2018 & -23.09 & -235.30 & 377.78 & 990.86 & 866.95 \\
2019 & -474.61 & -829.71 & 196.17 & 1222.05 & 996.49 \\
2020 & -967.37 & -1487.17 & 14.56 & 1516.29 & 1162.49 \\
2021 & -1496.59 & -2200.41 & -167.05 & 1866.31 & \\
\hline
\end{tabular}

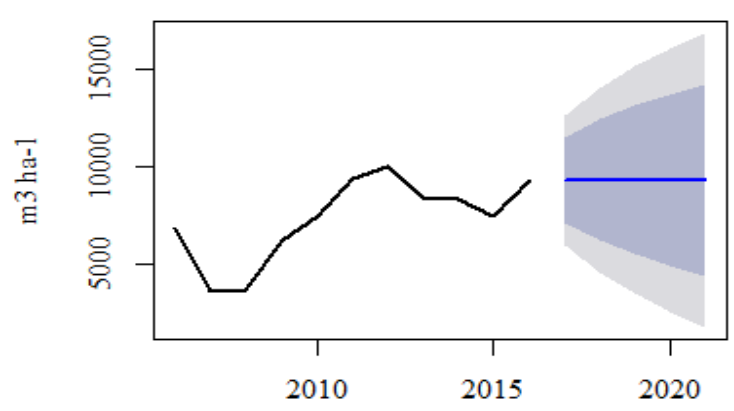

Figure 1. Annual irrigation water delivery per unit command area

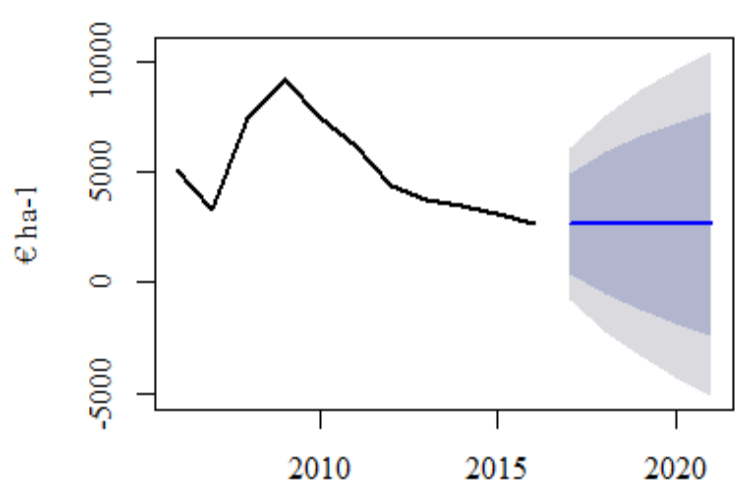

Figure 2. Output per unit command area

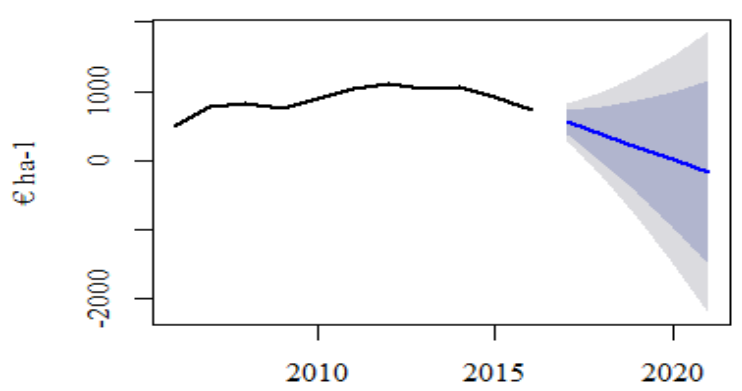

Figure 3. Total expenditure per unit command area

The data about total expenditure per unit command area until the year 2016 and estimated values for 2017 - 2021 period are presented in Figure 3. Total expenditure per unit command area decreased with the years. Estimated values are provided in Table 6 .
As can be seen in Table 4, at $80 \%$ probability, the lowest total expenditure per unit command area was calculated as $380.11 € \mathrm{ha}^{-1}$ and the greatest as $738.66 €$ ha $^{-}$ ${ }^{1}$ in 2017; the lowest value was calculated as $-1496.59 €$ ha $^{-}$ 1 and the greatest as $1162.49 € \mathrm{ha}^{-1}$ in 2021 . At $95 \%$ probability, the lowest total expenditure per unit command area was calculated as $285.21 € \mathrm{ha}^{-1}$ and the greatest as $833.56 € \mathrm{ha}^{-1}$ in 2017 ; the lowest value was calculated as $2200.41 € \mathrm{ha}^{-1}$ and the greatest as $1866.31 € \mathrm{ha}^{-1}$ in 2021 . As can be inferred from Figure 3, total expenditure per unit command area will decrease in years.

ARIMA model couldn't catch a trend in the indicators that annual irrigation water delivery per unit command area estimates. Therefore, forecast values are assumed same for the predicted years, however, vice versa for the indicator total expenditure per unit command area estimates. But, still upper and lower values of the indicators gives the range for the predicted years.

\section{Discussion, Conclusion and Recommendations}

Time series analysis with ARIMA model in agricultural studies, especially irrigation sector, are getting widely used to predict some values such as performance indicators (Arslan, 2020), irrigation management (Aljoumani et al., 2012), tank irrigation (Narayanamoorthy, 2007). The drought regions (Pamuk et al., 2004) show low performance in terms of irrigation ratio, indicates irrigated area over command area, due to lack of irrigation water (DSI, 2019). Water is the most important input in agriculture and its users are water user associations (WUA), so prediction of the performance of them is of great importance (Arslan, 2020).

The study support that time Series analysis is among the strongest tools used in forecasting future performance of irrigation schemes. Time Series - ARIMA method was used in present study to calculate future performance of Bergama irrigation scheme. With the use of ARIMA method, performance data of previous years were used and future performance of the irrigation scheme was forecasted. In this sense, annual irrigation water supply per unit command area, total expenditure per unit command area and output per unit command area of Bergama irrigation scheme for 2006-2016 period were used and forecasts were made for 2017-2021 period. Present findings revealed that there would be increases in upper limits of annual irrigation water supply 
per unit-command area and output per unit command area indicators and decreases in total expenditure per unit command area indicator in years. For Bergama irrigation scheme, annual irrigation water supply per unit-command area and output per unit command area were not consistent in 2006-2016 period. In other words, there was not a systematic increase or decrease in these parameters in years. Increases in some years were followed by a serious decline. Therefore, it was not possible to get point estimations for these parameters. Then, the lowest and the greatest possible values were calculated for these parameters. As compared to aforementioned two parameters, total expenditure per unit command area indicator was more consistent in 2006-2016 period. Analysis results revealed that such a case could also be reflecting in upcoming years. Therefore, it was forecasted that total expenditure per unit command area will continue to decrease in years. It was though that upper and lower limits calculated for three performance indicators would provide significant data for decision-makers to improve future performance of irrigation schemes. In line with present findings, relevant improvements and implementations should be put in practice.

\section{References}

Alcamo J, Döll P, Kaspar F, Siebert S. 1997. Global change and global scenarios of water use and availability: an application of WaterGAP 1.0. Center for Environmental Systems Research, University of Kassel, Kassel, Germany.

Alcon F, García-Bastida PA, Soto-García M, Martínez-Alvarez V. 2017. Explaining the performance of irrigation communities in a water-scarce region. Irrigation Science, doi: 10.1007/s00271-016-0531-7

Aljoumani B, Sànchez-Espigares JA, Canameras N, Josa R, Monserrat J. 2012. Time series outlier and intervention analysis: Irrigation management influences on soil water content in silty loam soil. Agricultural Water Management, 111: 105-114.

Anonymous 2020. Republic of Turkey Ministry of Agriculture and Forestry. Annual Report of 2019. Available from: https://cdniys.tarimorman.gov.tr/api/File/GetFile/425/KonuI cerik/759/1107/DosyaGaleri/dsi-2019-faaliyet-raporu.pdf [Accesed 16 February 2021]

Arslan F, Değirmenci H. 2018. RAP-MASSCOTE Aproach of modernizing operation-maintanence and management of irrigation schemes: A case study of Kahramanmaraş left bank irrigation scheme. Atatürk University Journal of Agricultural Faculty, doi: 10.15832/ankutbd.512677.

Boss MG, Murrray-Rust DH, Merrey DJ, Johnson HG, Snellen WS. 1994. Methodologies for assessing performance of irrigation and drainage management. Irrigation and Drainage Systems, doi:10.1007/BF00881553

Box GEP, Jenkins GM, Reinsel GC. 1994. Time series analysis; Forecasting and control, Prentice Hall, Englewood Cliff, New Jersey.

Burt C. 2001. Rapid appraisal process (RAP) and benchmarking explanation and tools. Retrieved in June, 10, 2020 from http://www.fao.org/3/a-aq443e.pdf

Campbell S, Diebold F. 2005. Weather forecasting for weather derivatives. Journal of the American Statistical Association, 100, 6-16.

Corcoles JI, Tarjuelo JM, Moreno MA, Ortega JF, De Juan JA. 2010. Evaluation of Irrigation Systems by Using Benchmarking Techniques. In: Proceedings of XVII. World Congress of the International Commission of Agricultural and Biosystems Engineering, 13-17 June, Québec City, Canada, pp: 225-234.
Çakmak B. 2001. Evalution of irrigation system performance in irrigation associations Konya. Tarım Bilimleri Dergisi 7: 111117.

Değirmenci H. 2004. Assessment of irrigation schemes with comparative indicators in Kahramanmaraş region. KSU Journal of Science and Engineering 7(1): 104-110.

DSI, 2019. Assessment report of irrigation facilities operated and transferred by DSI. General Directorate of State Hydraulic Works. Ankara, Turkey.

Engle R. 1982. Autoregressive conditional heteroscedasticity with estimates of the variance of United Kingdom ináation. Econometrica, 50: 987-1008.

Falkenmark M, Rockstrom J, Rockström J. 2004. Balancing water for humans and nature: The new approach in ecohydrology. Earthscan.

Kartal S, Değirmenci H, Arslan F. 2019. The effect of irrigation channel type and length on irrigation performance indicators. KSU J. Agric Nat., doi:10.18016/ksutarimdoga.vi.502821.

Kartal S, Değirmenci H, Arslan F. 2020. Assessment of irrigation schemes with performance indicators in southeastern irrigation district of Turkey. Journal of Agricultural Sciences. doi:10.15832/ankutbd.543990.

Malano H, Burton M. 2001. Guidelines for Benchmarking Performance in the Irrigation and Drainage Sector. IPTRID and FAO, Rome, Italy.

Mandal BN. 2005. Forecasting sugarcane productions in India with ARIMA model. New Delhi: IASRI

MCGLADE, 2012. Jacqueline et al. Measuring water use in a green economy, a report of the working group on water efficiency to the International Resource Panel. United Nations Environment Programme.

Millennium Ecosystem Assessment 2005. A Report of the Millennium Ecosystem Assessment. Ecosystems and Human Well-Being. Island Press, Washington DC.

Molden DJ, Sakthivadivel R, Perry CJ, Fraiture CD, Kloezen WH. 1998. Indicators for Comparing the Performance of Irrigated Farming Systems. IWMI, Colombo, Research Report 20: 26.

Narayanamoorthy A. 2007. Tank irrigation in India: a time series analysis. Water policy, 9(2): 193-216.

Neath A, Cavanaugh J. 2012. The Bayesian information criterion: Background, derivation, and applications. Wiley Interdisciplinary Reviews: Computational Statistics, doi:10.1002/wics.199.

Nelson D. 1991. Conditional heteroskedasticity in asset returns: a new approach. Econometrica, 59: 347-370.

Pamuk G, Özgürel M, Topçuoğlu K. 2004. Standart yֶă̆ış indisi (SPI) ile Ege Bölgesinde kuraklık analizi. Ege Üniversitesi Ziraat Fakültesi Dergisi, 41(1).

Renault D, Facon T, Wahaj R. 2007. Modernization of Irrigation Management: MASSCOTE Approach Mapping System and Services for Canal Operation Techniques. Food and Agriculture Org., 63: 13.

Rodríguez-Díaz JA, Camacho-Poyato E, Lopez-Luque R, PérezUrrestarazu L. 2008. Benchmarking and multivariate data analysis techniques for improving the efficiency of irrigation districts: An application in Spain. Agricultural Systems 96(13): 250-259.

Seckler D, Amarasinghe U, Molden D, de Silva R, Barker R. 1998. World water demand and supply, 1990 to 2025: scenarios and issues. Colombo, Sri Lanka: International Irrigation Management Institute (IIMI). vi, 40p. (IWMI Research Report 019 / IIMI Research Report 019) doi: http://dx.doi.org/10.3910/2009.019.

Shiklomanov IA, Rodda JC. 2003. World water resources at the beginning of the 21 st century. International hydrology series.

State Hydraulic Works 2017. 2. Ormancilık ve Su Şuras1- DSI Barajlar ve HES Dairesi Raporu. Afyonkarahisar: OSIB

State Hydraulic Works 2018. DSİ Genel Müdürlüğü Resmi Görüşü. Ankara: DSİ. 
Watershed Management Plans. 2019. Watershed Management Plans. Available from: https://www.tarimorman.gov.tr/SYGM/ Belgeler/NHYP\%20DEN\%C4\%B0Z/ULUSAL\%20SU\%20P LANI.pdf 2019 [Accesed 16 February 2021]
Zema DA, Nicotraa A, Mateosb L, Zimbonea SM. 2018. Improvement of the irrigation performance in water users associations integrating data envelopment analysis and multiregression models. Agricultural Water Management, doi:10.1016/j.agwat.2018.04.032 